\title{
BRITISH POLICY TOWARDS THE BALTIC STATES: 1939-1945
}

\author{
John Hiden
}

ABSTRACT Defending the Baltic States militarily after 1918 was not an option for British governments burdened by commitments to Imperial defence, and with only a skeletal British Expeditionary Force available to meet new European obligations incurred by the Treaty of Locarno. London saw stability and economic prosperity in the Baltic region as a whole as the real key to lasting independence for Estonia, Latvia and Lithuania. To this goal Britain made a vital contribution after 1918, as a recipient of Baltic agricultural and other exports, thus facilitating Baltic purchases of manufactured products from Germany. When the British-Baltic-German trade 'triangle' was destroyed by Hitler's arrival in power, the British government then used trade policy to try to limit the impact of the Third Reich in the Baltic region. Viewing the interwar period as a whole, it is easier to see both why Britain ultimately chose to resist Hitler over Baltic issues and why London was so reluctant to allow Stalin a free hand in the Baltic States during the Moscow negotiations of 1939. With the onset of war, however, Britain's very survival was at stake and it remains remarkable under such circumstances that so much effort continued to be expended by British officials in refusing to recognize the Soviet borders of 1941.

A pioneering article on this theme in the Journal of Baltic Studies some years ago suggested that the British government had a choice in its policy towards Estonia, Latvia and Lithuania; a choice between 'morality' on the one hand, 'expediency' on the other. ${ }^{1}$ The writer regarded the fact that Britain never formally acknowledged Soviet incorporation of the Baltic States as a fortuitous outcome of a British policy driven by expediency. He argued that Britain's reputation as champion of small states was saved only by Stalin's decision not to insist on the recognition of the Soviet borders of 1941, as a condition of signing an Anglo-Soviet agreement in $1942 .^{2}$ Quite apart from it

${ }^{1}$ D. Kirby, 'Morality or Expediency? The Baltic Question in British-Soviet Relations 1941-1942'. V. S. Vardys, R.J. Misiunas, eds., The Baltic States in Peace and war 1917-1945 (Pennsylvania, 1978), pp. 159-172.

${ }^{2}$ Ibid., p. 172. 
being difficult to find any such 'choice' available to British policy makers, the judgement does little justice to the agonizing over the Baltic question within the British government and Foreign and Commonwealth Office (FCO). It also perpetuates a widespread but mistaken belief of a Britain disinterested in far away European countries about which it knew nothing.

That idea barely survives even the most cursory review of British-Baltic relations after the First World War and it is in that general context that Britain's action from 1939 must be set. The United Kingdom's political, economic and military contribution to Baltic independence struggles 1918/1920 has long been acknowledged. The view that Britain virtually 'ran the Baltic' at that time finds support in recent studies of the peace settlement. ${ }^{3}$ These leave no doubt as to the formative roles of British officials and experts in the peacemaking process in Paris. ${ }^{4}$ True, there was initial scepticism about the capacity of the three Baltic countries to stand on their own economic feet. However, British documents manifest clear support for the Baltic peoples making their own political choices. London often indicated its displeasure at interference from Moscow in the Baltic countries, especially after the worsening of Anglo-Soviet relations in 1927.5

Nevertheless, British governments always believed that the only meaningful protection against undue Soviet influence was through lasting stability and prosperity in the Baltic region as a whole. To this goal Britain made a significant contribution. It became the leading recipient of Baltic agricultural and other exports, thereby helping the Baltic States to purchase vital manufactured products from Germany. Moreover, the British-Baltic-German trade 'triangle'

${ }^{3}$ Edgar Anderson, 'British policy towards the Baltic states 1918-1920.' Journal of Central European Affairs, 19 (1959), pp. 276-289.

${ }^{4}$ In general, A. Orde, British policy and European reconstruction after the First World War (Cambridge, 1990); E. Goldstein, Winning the Peace. British diplomatic strategy, peace planning and the Paris Peace Conference 19161920 (Oxford, 1991).

${ }^{5}$ See for example J. Hiden, 'Baltic banking. The German and British perspective'. Emancipation and Interdependence. The Baltic States as New Entities in the International Economy, 1918-1940 (Stockholm, 1994), pp. 307-319. Cf. lecture by J. Perowne to College of Imperial Defence from August 1932: He pointed out 'it was not necessarily to be assumed' that Estonia or Latvia would 'ultimately be incorporated with Russia, though that this fate was in store for them both was regarded as axiomatic a few years ago'. The National Archives, London [NA] (formerly Public Record Office (PRO)) F0 371/16292, N5579/5579/63. 
inexorably drew Estonia, Latvia and Lithuania into the west European- and world trading sector and away from their large eastern neighbour. ${ }^{6}$ Unfortunately, the situation was transformed with Hitler's arrival to power in 1933.

The event immediately gave British commercial policy a sharper strategic edge. There could be no longer any serious prospect of restoring the Anglo-German-Baltic trade triangle after the Great Depression. Instead, new British-Baltic trade treaties in 1934 deliberately capitalised on the desire of the Baltic countries to maintain exports to Britain. ${ }^{7}$ Foreign Secretary Sir John Simon asserted in January 1935 that 'Great Britain has used purchasing power over these countries to bring them into direct relations with herself, not exactly in alliance but it is an alignment of interest'. The head of the economics section of the FCO talked of Britain calling the Baltic into existence to redress the imbalance elsewhere. ${ }^{8}$

The pursuit of a British sponsored Scandinavian/Baltic trading bloc in the 1930s contrasts sharply with London's acknowledgement of its inability to slow down German economic penetration of south eastern Europe. ${ }^{9}$ The situation also explains why Britain's formal stand against Hitler opened in the Baltic arena, with the guarantee of Poland in March 1939. ${ }^{10}$ It also makes more sense of Britain's extreme reluctance to allow the Soviet Union a free hand in the Baltic States during the ensuing Moscow negotiations. Lord Strang, who was at the talks, confirmed that Britain wanted nothing less than 'a new and comprehensive system of security in Europe, both

${ }^{6}$ E.Hibbeln, Rivalen im Baltikum. Deutsche Reaktionen auf die britische Handelsvertragspolitik 1920-1935 (Frankfurt am Main, Berlin etc., 1997); J. Hiden, The Baltic states and Weimar Ostpolitik (Cambridge, 1987).

${ }^{7}$ See for example 'United Kingdom-Lithuanian Commercial Negotiations. Memorandum by the President of the Board of Trade' dated 29.6.1934. NA. Cabinet Records. Cab 24/249.

${ }^{8}$ Cited in P. Salmon, Scandinavia and the Great Powers 1890-1940 (Cambridge, 1997), p. 283. In general see P. Salmon, 'Anglo-German commercial rivalry in the Depression Era'. M.-L. Recker, ed., From Competition to Rivalry. The Anglo-German relationship in the countries at the European periphery, 19191939 (Stuttgart, 1986), pp. 101-141.

${ }^{9}$ See also H.G. Schröter, Aussenpolitik und Wirtschaftsinteresse. Skandinavien im aussenwirtschaftlichen Kalkül Deutschlands und Grossbritanniens 1918-1939 (Frankfurt am Main, etc., 1983).

${ }^{10}$ See J. Hiden, 'Baltic security problems between the two World Wars', J. Hiden, T. Lane, eds., The Baltic and the outbreak of the Second World War (Cambridge, 1992), p.1 ff. 
East and West, in the face of German ambitions'. ${ }^{11}$ Halifax could profess willingness in June 1939 'to meet the preoccupations of the Soviet government about the Baltic States' but he was adamant that this could only be 'done in a way which does not involve naming [the Baltic States] or giving the appearance of thrusting upon them a guarantee which would be highly distasteful to them'. ${ }^{12}$

In 1939, therefore, the British government chose not to defy one dictator by appeasing a second. Instead British officials remained true to their long-term policy. That is to say, they continued to try to embed Baltic independence in an overarching wider regional framework. Defending the individual Baltic republics militarily had never been an option after 1919. Britain's General Staff by 1939 argued that naval action in the Baltic was not worth the huge risks involved..$^{13}$ Moreover, London's absolute and inescapable existing commitment was to Imperial defence. Only a skeletal British Expeditionary Force was on hand to meet new European obligations incurred by the Treaty of Locarno. In a public lecture many years ago, the British historian Michael Howard once memorably compared Britain's defence tasks between the World Wars with having to play an entire musical score by Wagner on one penny whistle. ${ }^{14}$

Britain's strategy thus depended on surviving with France an initial German onslaught, before moving, in phases two and three of the war, to the containment and defeat of the Reich. Meanwhile, it had to deploy the resources of diplomacy to secure the benevolent neutrality or active assistance of other powers, particularly the United States of America. The immediate task for Britain was to counter what R. A. Butler called the 'appalling danger' of Germany and Russia combining material resources. ${ }^{15}$ In keeping with its longrange commercial strategy, Britain instituted 'war trade agreements' to restrict German access to British exports destined for the Baltic

11 Lord Strang, 'The Moscow negotiations.' D. Dilkes, ed., Retreat from Power. Studies in Britain's Foreign Policy of the Twentieth Century. Vol 1, 19061939, p. 175.

${ }^{12}$ Halifax to Sir William Seeds, 19.6.1939. E.L. Woodward, R. Butler, eds., Documents on British Foreign Policy. 1919-1939, 3rd Series, Vol. VI, p. 104.

13 But cf. the discussion by Salmon, Scandinavia and the Great Powers, pp. $317 \mathrm{ff}$.

${ }^{14}$ See also M. Howard's trenchant essay, 'British military preparations for the Second World War', Dilkes, ed., Retreat from Power, pp. 102-117.

${ }^{15}$ Cited in T. Lane, 'The Soviet occupation of Poland', The Baltic and the outbreak, p. 148. 
countries and Scandinavia. ${ }^{16}$ The desirability of Moscow's cooperation to make this particular exercise more effective was soon evident. Soviet soundings in March 1940 for an Anglo-Soviet trade agreement encouraged those in London who felt it was possible to draw Russia away from Germany.

In pursuit of this larger prize Britain's response to the Soviet occupation of eastern Poland had already been comparatively muted. ${ }^{17}$ That was not a particularly encouraging sign for the Baltic States, even though their significance to Britain was signalled by London approving legations for Tallinn and Kaunas in late March 1940, in addition to the established British post in Riga. In spite of this, the then British Ambassador to Moscow, William Seeds, had the impression that the treaties of mutual assistance imposed on Estonia, Latvia and Lithuania signified that they were already incorporated within the frontiers of the Soviet Union. By the time his successor, Stafford Cripps, first spoke with Stalin in Moscow on 1 July 1940, the Soviet takeover of the Baltic States was nearing completion. As far as The Times was concerned, moral condemnation had to take second place to the urgent need for agreement with the Soviet Union after the calamity of France's defeat. ${ }^{18}$

There is certainly a faint echo of this attitude in the record of the War Cabinet meeting of 17 June 1940, where Halifax presented Soviet actions as a strengthening of Soviet defences against Germany. However, Winston Churchill, who had now taken over from Neville Chamberlain, was keen to avoid any impression of running after the Soviet Union. He told Cripps in a carefully worded letter that, in relation to the Baltic States, 'You may affect the belief that the Soviet government recent action was dictated by the imminence and magnitude of the German danger now threatening Russia, in which case the Soviet government may well have been justified in taking in self defence such measures as might in other circumstances have been open to criticism'. ${ }^{19}$ What this masterly circumlocution

${ }^{16} \mathrm{Cf}$. letter from February 1940 to the Estonian government from the Board of Trade. NA. FO 371/24760/N1771/678/59. See also letter from Hall-Patch to the Bank of England 16.2.1940 noting there 'may be economic warfare advantages in tying up their (Estonian) sterling balances in some way.' Bank of England Archive, OV117/ 3 Estonia.

${ }^{17}$ Anita Prazmowska, Britain, Poland and the Eastern Front, 1939 (Cambridge, London, New York etc., 1987), p. 191.

${ }^{18}$ Cf. Times article of 5 July 1940 on the Soviet backed governments in the Baltic States and its leading article of 25 July 1940.

${ }^{19}$ NA 9 July 1940. Cab 66, Vol 6, 1940, WP (40) 254. 
barely reveals is that the British government saw the situation as provisional; it was signalling to Moscow that it did not exclude the restoration of Baltic independence in due course.

It was consistent with this position that Britain froze Baltic assets from 19 July 1940, including Baltic gold holdings. It also held captive Baltic ships present in British harbours. Legal justification for these actions rested on Britain's refusal to give official de facto recognition of the Soviet incorporation of the Baltic countries. Nor did the Soviet attack on Finland in August help Stalin's cause in Whitehall. Both cabinet and senior foreign office personnel at that point strongly resisted giving in to Soviet demands for the withdrawal of Baltic ministers from London. Churchill confirmed the formal policy of non-recognition in his parliamentary speech on 5 September 1940, calling for territorial frontiers to be settled only at the final peace 'in accordance with peoples who lived there.' Moreover, those peoples had to be 'free to chose own government and system of life, so long as they do not interfere with the similar rights of neighbouring peoples'. ${ }^{20}$

In spite of this, Stafford Cripps continued to press vigorously for Britain to reverse its policy. He urged the British government to accept the new situation in the Baltic States on the grounds that the Soviets had 'carefully observed the legal formalities' in their occupation of Estonia, Latvia and Lithuania. ${ }^{21} \mathrm{He}$ even seems privately to have gone beyond his brief - which was to secure a general agreement with Russia. He implied to the Russians in October 1940 that Britain's de facto recognition might be secured in return for Russia's neutrality in the war against Germany. Nothing official appears to have come of this hint but Cripps' suggestion was later exploited by Moscow to justify the non-involvement of America in the 1942 Anglo-Soviet talks. Obviously Cripps had convinced himself at least that Britain's position would not be compromised by de facto recognition. Without this, he warned once more at the end of 1940, there would be no Anglo-Soviet economic agreement. Britain's urgent need of such agreement was underlined by news of fresh German-Soviet trade deals early in 1941.

Although Eden's appointment as foreign secretary on 2 January 1941 brought improvement in his office's relations with the Russian embassy in London, his staff had yet to reach any consensus on

${ }^{20}$ Cited Kirby, 'Morality or Expediency?', p. 160.

${ }^{21}$ NA FO 371 24761. N6081/1224/59. 7.8.1940 
Cripps' arguments. A Foreign Office memorandum at the beginning of January 1941 argued that sovereignty could only be attached to de jure recognition - criticising Cripps' references to de facto sovereignty; ${ }^{22}$ another opinion held that the very act of withdrawing the British Baltic Legations, as well as the discussion of British interests with Moscow, in effect already amounted to a de facto recognition of Soviet authority. This perception became more common as the war situation worsened. Significantly, Cripps received instructions in January 1941 that de facto recognition 'would only be considered by His Majesty's Government if it would produce some definite advantage, such as the cessation or considerable diminution of Soviet economic help to Germany, or Soviet interference with German plans in the Balkans'. 23

This appears to have been the first unambiguous hint of possible bargaining over recognition, even though British policy remained ostensibly the same as it had been in 1939. Certainly, Cripps took his recall from the Soviet Union in June 1941 as a personal failure. ${ }^{24}$ The truth was that within the British government and Foreign Office there was a broad acceptance that while the legal distinction between de facto and de jure recognition might not be great, the political difference was enormous. In this respect the known hostility of the United States government to any compromise on recognition made itself felt in London. Of course, the Americans were hardly likely to prevent the conclusion of a general Anglo-Soviet agreement on mutual assistance in July 1941, arising from Hitler's invasion of the Soviet Union. This agreement has sometimes been criticised for not specifically referring to the principles Churchill had set out in parliament the previous September. ${ }^{25}$ It seems an odd objection, not least because Britain's adherence to the Atlantic Charter one month later again publicly committed it to oppose territorial changes before the peace settlement, and to take into account the

${ }^{22}$ NA FO 371 24849. N7548/40/38 Memo of Fitzroy Maclean 1.1.1941. Cited A.P. McManus, Great Britain, the Baltic Republics and the Soviet Union 19391945. Unpublished Mphil, Bradford, 1994, pp. 177-178.

${ }^{23}$ NA FO 371 29463. N411/3/38. 2.1.1941

${ }^{24}$ On Cripps' expectations see M. Nurek, 'Great Britain and the Baltic Sea: 1939/40 and 1945'. H. Runblom, M. Nurek, M. Burdelski, T. Jonter, E. Noreen, eds., 50 years after World War II. International Politics in the Baltic Sea Region (Gdańsk, 1997), p. 103.

${ }^{25}$ Kirby, 'Morality or Expediency?', p. 160-161. 
free expression of the populations involved - a document that the Soviet Union also signed the following month.

Clearly, a 'tripartite' world order was already beckoning from the distance in 1941 but the immediate burden of war fell still on London and Moscow. It linked the British and Russian people emotionally in the deadly struggle against Hitler's Germany. In doing so it helped to create a public mood more encouraging to those politicians who wished to maintain that close relations with the USSR in the post-war world would be more important to Britain than the fate of the Baltic countries. ${ }^{26}$ Eden was one of those figures. Of course, he acknowledged the Atlantic Charter as the basis for any post-war order; of course he also knew that if it came to a forced choice between allies, Britain would have to side with the United States. This is quite evident from his memorandum for the War Cabinet of 26 November $1941 .{ }^{27} \mathrm{He}$ penned it prior to his visit to Moscow in December to discuss Soviet demands for extensions to the July treaty, as well as clarification of joint war aims. All the same, Eden went as a person who had already signalled a strong interest in placating Moscow, not least by discontinuing formal Foreign Office receptions for Baltic ministers in London from August 1941. ${ }^{28}$

At the Moscow talks opening on 16 December 1941, attended by Cripps and Sir Alexander Cadogan as well as Eden, Stalin very soon made clear that for the USSR the Baltic question was 'absolutely axiomatic.' According to Maisky, Eden was well disposed towards Soviet draft terms referring to post-war recognition of the USSR's frontiers of June 1941, but unwilling to accept Stalin's suggestion of a secret protocol referring to immediate British recognition. British documents confirm Maisky's account. Eden tried to reassure Stalin, 'that we do not recognize the independent existence of any of these states. They have no diplomatic status with us, but we are committed to the United States of America not to bind ourselves as to any decision upon European frontiers before the end

${ }^{26}$ In general, D. Reynolds, 'Great Britain: Imperial Diplomacy'. D. Reynolds, W.F. Kimball, A.O. Chubarian, eds., Allies at War. The Soviet, American and British Experience 1939-1945 (London, 1994).

${ }^{27}$ NA Cab 66, Vol. 20. WP (41) 288.

${ }^{28}$ On the status of Baltic representatives in London see W.J.H. Hough III, 'The Annexation of the Baltic States and its Effect on the Development of Law Prohibiting Forcible Seizure of Territory'. New York Law School Journal of International and Comparative Law, 6(1985), pp. 414-415. 
of the war without consultation with them. I am however prepared to seek a decision from my government on this issue and consult the Americans. I think it is most desirable that all three governments come to an agreement on this question'. ${ }^{29}$

In London the War Cabinet examined carefully but finally rejected Stalin's demands, if rejection is quite the word to describe the ensuing telegram sent to Eden. 'A refusal on our part to pledge ourselves at this stage as regards Russian territorial claims does not, of course, mean that we are necessarily opposed to the Soviet Union re-annexing the Baltic States... at the peace, but we do not see that at the present stage you can go further than you have done'. ${ }^{30}$ It might be added that Eden had gone quite far in his December talks with Stalin. In response to a question about Britain's attitude in the event of the Red Army seizing control of the Baltic States, Eden personally surmised that London would be delighted; such a fait accompli, it was implied, would leave Britain little choice. In reality the British government as a whole was not prepared to assume the responsibility of agreeing to the 1941 frontiers, so that Moscow delayed any final signature of the agreement on military cooperation and post-war reconstruction.

Eden responded by intensifying his efforts to convince the British government and parliament that the question of frontiers was the 'acid test' for the Soviet Union, without which there would be no Anglo-Soviet agreement. His 5 January 1942 telegram to Churchill proposed immediate acceptance of Moscow's demands, on the grounds that neither the United States nor Great Britain would be able to influence the outcome of the war for the Baltic States. Convinced that Britain needed Russian help more than Russia needed the United Kingdom, Eden even contended that the stage-managed Soviet plebiscites in the Baltic countries in July 1940 met the obligation to take the people's will into account, as demanded of signatories to the Atlantic Charter. In addition Eden argued that a strong Russian presence in the Baltic would be an invaluable check to Germany - at least as long as the balance was redressed though

${ }^{29}$ Extensive extracts from the document in McManus, Great Britain, pp. 230 235. See also, D. Thorpe, Eden. The Life and Times of Anthony Eden First Earl of Avon (London, 2004), pp. $267 \mathrm{ff}$.

${ }^{30}$ NA FO 371 29655. N 7483/7462/38. 19.12.1941. Kirby, 'Morality or Expediency?', p. $161 \mathrm{ff}$. 
the Soviet Union acknowledge Britain's right to have bases on the European mainland. ${ }^{31}$

Eden elaborated his arguments once more in a memorandum of 28 January 1942 for a War Cabinet meeting. Soviet claims vis-à-vis the Baltic States were described as 'very reasonable' in view of what the USSR had endured. Eden then proposed that Stalin be allowed to interpret the Atlantic Charter in such a way that his promised rejection of territorial expansion applied only to the Soviet borders prior to the German invasion in 1941. Eden urged that if ultimately forced to accede to American wishes, then Britain should persuade Washington to permit Soviet military bases on territories bordering Russia - especially in the Baltic and Black Sea - as well as sanctioning Soviet control of Baltic foreign and defence policy. Perhaps the kindest response today to such a document is to recall the unenviable position of being a foreign minister where, in Eden's own words, Soviet policy was amoral, that of the United States excessively moral - especially when its own interests were not at stake.

Nor is Churchill's restatement of British policy in his letter to Eden on 8 January 1942 entirely free of the ambiguity infecting the debate over the Baltic question. 'We have never recognized the 1941 frontiers of Russia', Churchill observed, 'except de facto'. At least he went on to make plain that 'the transfer of the Baltic States to Soviet Russia against their will would be contrary to all the principles for which we are fighting this war and would dishonour our cause. ...In any case there can be no question of settling frontiers until the Peace conference'. He also reminded Eden of his promise to discuss Russia's claims with the United States. In opposing concessions to the Soviet Union Churchill could draw on the support of Atlee, who chaired the committees on the Armistice Terms and Post-war Settlement, and a number of members of Parliament. In the Foreign Office, Cadogan, a fervent Atlanticist, also did what he could to dissuade Eden, noting in his diary that Britain 'should not crawl to the Russians over the dead bodies of our principles'. ${ }^{32}$ On the other hand, Eden found support in the Cabinet from Beaverbrook, Morrison and Sinclair, as well as most senior officials in the Foreign Office. ${ }^{33}$

Any suggestion that neither the British public nor most officials cared much for the Baltic States at this stage is therefore only

${ }^{31}$ Ibid.

${ }^{32}$ Printed in W. Churchill, The Grand Alliance (London, 1950), p. 630.

${ }^{33}$ See Reynolds, 'Great Britain'. 
partially accurate. It was rather the continuing misfortunes of war in the winter of $1941 / 1942$ that inexorably won over doubters to Eden's Realpolitik. A War Cabinet Meeting of 6 February 1942 finally agreed to ask for American agreement to British recognition of the USSR's 1941 frontiers or, failing that, support for the idea of Soviet bases in the Baltic countries and some Soviet say over foreign and defence policy. The resolution in Churchill's 8 January letter to Eden was manifestly weakened by the time he wrote his personal telegram of 7 March 1942 to Roosevelt. In this Churchill specifically referred to the gravity of the war forcing him to think that the principles of the Atlantic Charter 'ought not to be so construed so as to deny Russia the frontiers she occupied when Germany attacked her. This was the basis on which Russia acceded to the charter.' 34 Expressing his feeling that Russia had already liquidated hostile elements in the Baltic States at the outset of the war, Churchill asked Roosevelt for a free hand to sign the agreement Stalin wanted 'as soon as possible.'

Churchill was in effect simply adding his own considerable personal weight to the arguments already advanced by Halifax in a private meeting with Roosevelt on 17/18 February 1942, where the former reminded the American president of the failure of the AlliedSoviet talks in 1939 over the Baltic question. Ultimately, Roosevelt not only rejected any deal over the 1941 frontiers but also intimated his intention of taking the question up directly with Stalin. Hostile references by the United States' government to avoiding a 'Baltic Munich' showed an impressive failure to grasp the immediate and harsh reality of war for Britain in 1942, apart from being inappropriate. It was no longer feasible for Britain to maintain a blunt rejection of Stalin's calls for recognition of the USSR's borders of June 1941 as a precondition of any Anglo-Soviet agreement. Churchill was fixated on the defeat of Germany but haunted by the possibility of a separate German-Soviet agreement in the absence of any immediate prospect of an Allied front.

Some historians argue that only when in May 1942 the Americans dangled the bait of a second front, did Stalin decide not to insist on British recognition of the USSR's June 1941 frontiers. It is worth remembering, however, that the War Cabinet discussions on 7 May p. 165.

${ }^{34}$ Cited McManus, Great Britain, p. 288; Kirby, 'Morality or Expediency?', 
came out against giving into Soviet demands on this point, if admittedly because of fears of prejudicing the eventual position of Poland. It was this refusal that sparked the alternative draft for an AngloSoviet agreement to be prepared in the Northern Department of the FCO. While agreeing to build a post-war alliance against German aggression, the new version omitted the frontier question entirely. To one historian at least this was an example of expedience winning out over morality. ${ }^{35}$ In fact it was wholly consistent with Britain's preference for not anticipating the post-war configuration of the Baltic area - even though most accepted by then the likelihood of Soviet control. To represent the new American hints about building a second front as sparing British blushes is also to forget that the prospect of Germany being tied up in this way increased the likelihood of the Red Army, sooner rather than later, re-occupying the Baltic States.

With some relief Churchill famously recorded that the final treaty of 26 May 1942 was 'a far better solution than I had dared to hope'. Even so, not long afterwards Soviet pressure saw the removal of the Baltic envoys in London from the annual diplomatic lists, one of a number of indicators that by 1942 the die had already been cast for the Baltic States. Moreover, apart from this action it is hard to see any obvious difference between the British and American positions. ${ }^{36}$ By the time the Soviet leader held his first meetings with Roosevelt and Churchill at Tehran in the winter of 1943 to discuss the reconstruction of Europe after the war he bluntly insisted, however, that he would consider no change of status for the Baltic States. Churchill told Eden in January of that year of his growing confidence in Stalin after the impressive Soviet military victories. He acknowledged the likelihood that the Baltic States would soon be under Russian control again 'and it is absolutely certain that we should never attempt to turn them out'. That much was indicated in his speech to the British parliament on 22 February 1944.

To view this outcome as the triumph of expediency over morality is to lose sight of the larger picture. Soviet reoccupation later in 1944 was part of the price the British and American governments had to pay to sustain the tripartite struggle to win the war - taking the matter of the future of the Baltic States far beyond the influence of London alone.

${ }^{35}$ Kirby, 'Morality or Expediency?', p.172.

${ }^{36}$ See Martin Gilbert, Churchill. A Life, 2nd edition (London, 2000), p. 715. 


\title{
BRITANIJOS POLITIKA BALTIJOS VALSTYBIŲ ATŽVILGIU
} 1939-1945 M.

\author{
Santrauka
}

\section{JOHN HIDEN}

Baltijos valstybiu gynimas ginklu po 1918 m. Didžiosios Britanijos vyriausybėms, turejjusioms problemų su savo imperijos saugumu, nebuvo prioritetas. Juo labiau, kad vykdydamos naujus Lokarno sutarties ipareigojimus Europoje, jos disponavo tik menkomis savo ekspedicinemis pajègomis. Apskritai Baltijos regiono stabilumą ir ekonominę gerovę Londonas laikè realia prielaida ilgalaikei Estijos, Latvijos ir Lietuvos nepriklausomybei. Šiuo atžvilgiu po $1918 \mathrm{~m}$. Britanija daug padèjo Baltijos valstybėms, pirkdama jų žemès ūkio bei kitą produkcija, taip joms padėdama įsigyti pramonès produkcijos iš Vokietijos. Kai Hitleriui atẻjus į valdžią buvo sugriautas britų-baltų-vokiečiu prekybos ,trikampis“, Britanijos vyriausybè èmési prekybos politikos, siekiančios apriboti Trečiojo Reicho įtaką Baltijos regione. Atsižvelgiant i visą tarpukario politikos kontekstą, darosi aiškiau, kodèl Britanija pagaliau pasipriešino Hitlerio planams Pabaltijyje ir kodèl Londonas taip nenoriai leido Stalinui laisvai elgtis su Baltijos valstybėmis 1939 m. derybose su Maskva. Tačiau karui prasidejjus, kai pačios Britanijos likimas pakibo ant plauko, vis dèlto stebètina, kad britų diplomatai ir toliau dejjo tiek daug pastangu, atsisakydami pripažinti Sovietų Sajungos $1941 \mathrm{~m}$. sienas.

\section{Author Details}

John Hiden is professor of Modern European History in the Univerity of Bradford, England. His research interests are in the twentieth-century history of the Baltic States and the policy of the Weimar Republic towards the Baltic region.

Email: j.hiden@bradford.ac.uk 